hard hat. Bruce describes the ironic observations of the Pastusos (the residents of Pasto, the city near Galeras). They had lived for decades near the volcano without many fatal accidents, yet saw how eagerly volcanologists went to the only place that was really dangerous. Did these researchers really know much? Could they be trusted to tell Pastusos how to live with the volcano, or when to evacuate their homes? Tragically, three Pastusos actually followed the scientists into the crater, encouraged by their nonchalance. The tourists all died.

It is ironic that the educated experts who were going to develop a safety plan for the public paid so little attention to their own safety. Safety measures are at least partly for show - to make people aware of danger. Because often a volcano erupts less than once in a human lifetime, building public awareness of danger is especially crucial in this case. If scientists had been seen in protective gear by those watching near the crater or on television, it would have helped to show that the experts were aware of possible danger. I doubt that any international hazards workshop will ever again forget this.

Williams' comments on seismology also have a tragic irony, as long-period seismic signals were warning of an impending eruption, if anyone had acknowledged the fact. It was realized very soon after the eruption, and both books discuss this at length. Long-period earthquakes are associated with rising magma and degassing, and occur hours or days before an eruption. They were scientific 'hot buttons' at the time of Galeras.

Bruce points out that Williams was aware of this. He had previously mentioned the need to correlate seismic and gas data in a proposal written after a meeting in Pasto, where Bernard Chouet of the US Geological Survey explained to Williams and others that long-period events could be useful for inferring gas-related phenomena and predicting eruption. Williams claims that he realized only after the 1993 eruption that long-period events might presage an eruption. But seismic signals of this type had preceded a Galeras eruption in July 1992. Bruce notes that John Stix had written an abstract to be presented at the January 1993 workshop that recognized the analogy between the July 1992 and January 1993 situations.

So why were the long-period signals not noted and recognized as a warning before the January 1993 crater visit? It seems that the scientists knew of the new ideas - but didn't really trust them or use them. They would cite them in their proposals and abstracts, but when it came to deciding whether to go to the crater, they didn't think them important. Scientists from the US Geological Survey, who might have forcefully pushed Chouet's ideas, missed the Galeras meeting because they couldn't get travel clearance. Was their absence a factor in the disaster? Was it bravado, scientific rivalry, or just ignorance, as Williams asserts, that caused the warning to be overlooked? If it was rivalry, how can we minimize this in similar circumstances?

The existence of two books about the same events makes them much more valuable, because they each present the events of the Galeras workshop and the fatal eruption from a very different perspective and with different emphasis. Williams describes the lure and lore of volcanology, and I suggest you read him first. He portrays in some detail the people who died; these were Williams' kind of volcanologists, and all remarkable. Igor Menyailov is Williams' ultimate hero; Bruce, on the other hand, criticizes Menyailov as reckless.

In her book, Bruce forcefully points out Williams' mistakes (although, in fairness, Williams recognizes some of them too), using careful interviewing and library research. She focuses on Colombia's volcanologists and the development of an infrastructure to deal with volcanic hazards there. She also considers the Nevado del Ruiz disaster of 1985, in which more than 23,000 people died. This was a most spectacular failure of efforts to mitigate volcanic hazards - a much more tragic event than Galeras.

For those of us trying to help with technology transfer and infrastructure building for natural hazard mitigation in less-developed countries, Bruce's detailed examination of this disaster is praiseworthy. Her thoughtful discussion makes it clear that Colombia lost by far the most from both the Ruiz and Galeras incidents. The increasing emphasis on foreign work in natural hazards areas makes intercultural communications a vital skill. Volcanologists have much to learn here.

This review may seem highly critical of Williams, but that is largely bad luck (his). He was unlucky in that he was the senior scientist, who had convened the workshop, and therefore was held responsible for the disaster. Many of us could easily have been in the same shoes. All who have been in similar situations have made mistakes, which, in hindsight, put people in danger that we and they didn't fully appreciate. We never had to own up to these mistakes because nothing bad happened on our watch. My hope is that volcanologists (and other scientists) read these books and recognize the mistakes that might haunt their profession. As Williams says, "people in high risk professions are confident they can beat the odds".

William I. Rose is in the Department of

Geological Engineering and Sciences,

Michigan Technological University,

1400 Townsend Drive, Houghton, Michigan

49931-1295, USA.

\section{Too faint \\ a flavour?}

Flavour and Fragrance Chemistry edited by Virginia Labzotti

\& Orazio Taglialetela-Scafati

Kluwer Academic: 2000. 256 pp.

$£ 74.50, \$ 117.50$

\section{Peter Waterman}

The chemistry underlying our perceptions of flavour and fragrance is both fascinating and complex. Although fragrance phenomena are predominantly associated with relatively small, volatile molecules, usually occurring in complex mixtures, the structural range and size of compounds associated with flavour are far greater.

Given that the book under review is volume 46 of the Proceedings of the Phytochemical Society of Europe, a series that has produced many notable publications on natural products, I was anticipating a 'good read' to bring me up to date on these topics. Unfortunately, I was more than a little disappointed.

Why am I being so negative? It is not primarily due to the quality of the individual contributions, although they are variable. But with 23 papers and only 250 pages of text, the average length of each contribution is less than 11 pages and the individual papers are, for the most part, simply reports of the work (generally previously published) of the authors. This means we are offered tantalizing fragments on individual subjects, but rarely placed in any review context. The editors have attempted to arrange the chapters according to subject area, but I did not find that their efforts helped to rationalize the disparate topics. It also has to be said that some of the topics have only a peripheral bearing on the subject (for example, alkaloids from Amaryllidaceae, cell cultures of Hypericum perforatum for high-value metabolites, antioxidants).

I cannot reconcile the content or the depth of the papers in this volume with my expectations for the flagship series of a prestigious society. When I pick up a volume of the Proceedings of the Phytochemical Society of Europe I expect to find erudite and comprehensive reviews of the title subject. This collection of worthy but limited contributions would be better suited to a 'special issue' of an appropriate journal or a cheaper, soft-covered, conference report.

I would not recommend this book to a hard-pressed librarian trying to make ends meet. It is, quite simply, not worth the price.

Peter Waterman is at the Centre for Phytochemistry, Southern Cross University, PO Box 157, Lismore, New South Wales 2480, Australia. 